\title{
Role of GnRH in the regulation of pituitary GnRH receptors in female mice*
}

\author{
S. I. Naik, L. S. Young, G. Saade, A. Kujore, H. M. Charlton $\dagger$ and \\ R. N. Clayton
}

Department of Medicine, University of Birmingham, Birmingham B15 2TH, and $\dagger$ Department of Human Anatomy, University of Oxford, South Parks Road, Oxford OXI 3QX, U.K.

Summary. The fall in pituitary GnRH receptors in female mice after ovariectomy (Ovx) was further decreased $(>50 \%)$, rather than prevented, by treatment with a GnRH antiserum, despite suppression of the post-gonadectomy increase in serum gonadotrophins, suggesting that increased endogenous GnRH secretion is not the mediator of GnRH receptor fall after ovariectomy in mice. Furthermore, GnRH antiserum reduced $\mathrm{GnRH}$ receptors by $30-50 \%$ in intact normal females, without altering receptor affinity, and rendered serum LH and FSH undetectable but did not reduce receptors in GnRH-deficient, hpg mice.

When GnRH was administered to ovariectomized mice this failed to restore receptor values ( $\mathrm{fmol} /$ pituitary) (intact $=55 \cdot 3 \pm 2 \cdot 4 ; \mathrm{Ovx}=30 \cdot 1 \pm 2 ; \mathrm{Ovx}+\mathrm{GnRH}$ $=31.6 \pm 2.8)$, but serum $\mathrm{LH}$ was reduced from high post-ovariectomy values ( $231 \pm$ $42 \mathrm{ng} / \mathrm{ml})$ to values normal for intact females $(24 \pm 2 \mathrm{ng} / \mathrm{ml})$. In contrast, multiple $\mathrm{GnRH}$ injections to intact female mice increased $\mathrm{GnRH}$ receptor by $35 \%$, while serum $\mathrm{LH}$ was reduced to just detectable levels. A marked dissociation between GnRH receptor and serum gonadotrophin concentrations was observed.

Administration of oestrogen $\left(E_{2}\right)$ plus progesterone $(P)$ to ovariectomized mice in which endogenous $\mathrm{GnRH}$ had been immunoneutralized reversed the inhibitory effect of GnRH antiserum on GnRH receptors and increased values above those of ovariectomized controls, although no increase in serum or pituitary gonadotrophin levels was seen in ovariectomized mice treated with $E_{2}+P+G n R H$ antiserum.

Treatment with $E_{2}$ and $P$ of intact females receiving GnRH antiserum did not prevent the inhibitory effect of antiserum on receptors, while $E_{2}+P$ treatment alone of intact female mice reduced GnRH receptors by $30 \%$. These data suggest that the gonadal steroids reduce GnRH receptors in intact female mice by inhibiting hypothalamic GnRH secretion, and that a certain degree of pituitary exposure to GnRH is required for maintenance of a normal receptor complement.

These results suggest that (1) the fall in GnRH receptors after ovariectomy is primarily attributable to removal of gonadal factors. The fall is not a reflection of alteration in endogenous GnRH interaction with the gonadotroph; (2) homologous ligand 'up-regulation' of $\mathrm{GnRH}$ receptors in female mice depends upon the presence of the ovaries; (3) endogenous $\mathrm{GnRH}$ is also required for $\mathrm{GnRH}$ receptor maintenance in intact female mice; and (4) GnRH receptor and serum gonadotrophin responses to hormonal changes can be dissociated and their relationship is complex.

* Reprint requests to Dr R. N. Clayton. 


\section{Introduction}

Gonadectomy in rats is invariably associated with a 2-3-fold rise in gonadotrophin-releasing hormone receptors coincident with the rise in serum gonadotrophins (Frager, Pieper, Tonetta, Duncan \& Marshall, 1981; Clayton \& Catt, 1981a; Conne, Scaglioni, Lang, Sizonenko \& Aubert, 1982). These responses can be prevented by immunoneutralization with a specific GnRH antiserum (Frager et al., 1981; Clayton, Popkin \& Fraser, 1982) suggesting that increased endogenous GnRH is essential for the post-gonadectomy rise in pituitary GnRH receptors and serum gonadotrophins. Studies of ewes (Fraser \& McNeilly, 1982) and castrated rats (Kawakami \& Higuchi, 1979) have shown that passive immunoneutralization of endogenous GnRH results in a rapid and sustained decrease of the high serum LH and FSH concentrations. Moreover, immunoneutralization of GnRH prevents the preovulatory surge of LH in rats (Arimura, Debeljuk \& Schally, 1974) and sheep (Fraser \& McNeilly, 1982). We have demonstrated a GnRH-receptor response to gonadectomy in mice that is opposite that found in rats, although the serum gonadotrophin (Naik, Young, Charlton \& Clayton, 1984a) responses are the same. There is therefore no positive correlation between pituitary content of GnRH receptors and serum gonadotrophin secretion after gonadectomy of mice.

Pituitary GnRH receptors can be induced in rats by intermittent administration or continuous infusion of low doses of GnRH or an agonist analogue (Clayton, 1982), and GnRH rapidly increases GnRH receptors in the pituitaries of mice with an inherited absence of hypothalamic GnRH (hpg) (Young, Speight, Charlton \& Clayton, 1983). Homologous up-regulation of GnRH receptors also occurs in cultured rat pituitary cells (Loumaye \& Catt, 1982; Conn, Rogers \& Seay, 1984; Young, Naik \& Clayton, 1984). Thus, GnRH positively regulates its own pituitary receptors, and pituitary exposure to $\mathrm{GnRH}$ seems to be essential for the maintenance of a normal receptor number. The present study was therefore designed to analyse the importance of endogenous GnRH in the fall of GnRH receptors after ovariectomy of mice. We reasoned that, if excessive endogenous GnRH secretion after ovariectomy was responsible for the receptor fall, then this should be prevented by specific immunoneutralization of endogenous GnRH. Alternatively, if the receptor fall after ovariectomy was due to a relative deficiency of endogenous GnRH secretion then it should be reversed by exogenous GnRH treatment. Consequently, the role of $\mathrm{GnRH}$ in its own receptor regulation was determined in ovariectomized and intact female mice, and compared with serum and pituitary gonadotrophin changes.

\section{Materials and Methods}

Hormones. The GnRH agonist analogue (D-Ser(t But) ${ }^{6}$ des Gly $\left.{ }^{10}\right) \mathrm{GnRH} N$-ethylamide (GnRH-A), used for iodination and as standard for the radioreceptor assay (RRA), was kindly donated by Dr $J$. Sandow (Hoechst A.G. Frankfurt, West Germany). GnRH antiserum (sheep anti-GnRH serum No. 94) was kindly supplied by Dr H. M. Fraser, Edinburgh.

Animals and sample collection. Normal and hpg (GnRH-deficient) male and female mice (C3H/HeH/101 H Fl hybrid strain intercrosses) aged 80-180 days (25-35 g) were obtained from the Department of Anatomy, University of Oxford. Female mice were housed, from the time of weaning as 6-8 animals per cage (size $=21 \times 28 \times 10 \mathrm{~cm}$ ), in the same room as male mice from birth until experiment, with $14 \mathrm{~h}$ light/ $24 \mathrm{~h}$ and free access to Purina chow and tap water. All females were used at random stages of the oestrous cycle. Ovariectomy was performed through a single dorsal incision and orchidectomy was carried out by way of a scrotal incision under light ether anaesthesia. At the completion of experiments, all animals were killed by decapitation, trunk blood was collected and serum separated and stored at $-20^{\circ} \mathrm{C}$ until RIA. Pituitary glands were rapidly removed, snap-frozen in liquid nitrogen and stored at $-70^{\circ} \mathrm{C}$ until GnRH RRA. 
Radioreceptor and radioimmunoassays. GnRH receptor numbers were measured in an aliquant of an individual normal mouse pituitary homogenate by equilibration at $4^{\circ} \mathrm{C}$ for $90 \mathrm{~min}$ in a total volume of $135 \mu \mathrm{l}$ with a near-saturating concentration (1 $\mathrm{nM})$ of $\mathrm{GnRH}$ agonist as the ligand, including 100000 c.p.m. of the radioiodinated analogue. Non-specific binding was measured in the presence of a 200 -fold excess of unlabelled GnRH-A. Pituitary receptors of $h p g$ female mice were measured under non-saturating ligand conditions. This method allows duplicate determination of total and non-specific binding for each individual pituitary homogenate; the difference between these values, the specific binding, was converted to receptor concentration as femtomoles GnRH-A bound per pituitary. Values were corrected for difference in protein concentration between glands. The details of the methodology were as described previously (Naik et al., 1984a).

Serum and pituitary LH, FSH and prolactin concentrations were measured by RIA as described by Naik et al. (1984a, b), and results are expressed in terms of the rat RP-2 standard. The inter- and intra-assay coefficients of variation for $\mathrm{LH}, \mathrm{FSH}$ and prolaction RIAs were $8-10 \%$ and $3-5 \%$, respectively. The lower limit of detectability for serum LH (bound counts/bound counts in the absence of added unlabelled hormone $=0.9$ ) varied between 19 and $25 \mathrm{ng} / \mathrm{ml}$ and the value for each experiment is presented in the corresponding Table or Text-figure legend. The limit of detection for serum FSH was $50 \mathrm{ng} / \mathrm{ml}$.

Statistical analysis. When appropriate, differences between groups were examined by the Mann-Whitney U-test or analysis of variance and Student's $t$ test.

\section{Results}

Dose-response effect of GnRH-antiserum in intact and ovariectomized normal female mice (Table I)

Groups of ovariectomized normal mice were injected s.c. with $50,10,5$ or $2 \mu \mathrm{l} \mathrm{GnRH}$ antiserum or non-immune sheep serum once daily for 5 days, commencing at the time of ovariectomy. Two groups of intact normal female mice were given 50 or $10 \mu \mathrm{l} \mathrm{GnRH}$ antiserum once daily for 5 days and a third group of intact normal females was injected with $10 \mu \mathrm{l}$ non-immune sheep serum (control). Animals were killed $24 \mathrm{~h}$ after the last injection of antiserum.

Table 1. Dose-response effect of GnRH antiserum (AS) in intact and ovariectomized (Ovx) normal female mice

\begin{tabular}{|c|c|c|c|c|c|c|}
\hline & Groups & $\begin{array}{l}\text { GnRH receptor } \\
\text { (fmol/pituitary) }\end{array}$ & $\underset{(\mathrm{ng} / \mathrm{ml})}{\text { Serum LH }}$ & $\underset{(\mathrm{ng} / \mathrm{ml})}{\text { Serum FSH }}$ & $\begin{array}{l}\text { Pituitary LH } \\
\text { ( } \mu \mathrm{g} / \text { pituitary) }\end{array}$ & $\begin{array}{c}\text { Pituitary FSH } \\
\text { ( } \mu \mathrm{g} / \text { pituitary) }\end{array}$ \\
\hline & $\begin{array}{l}\text { Intact female + } \\
\text { vehicle }\end{array}$ & $53 \cdot 1 \pm 2 \cdot 5$ & $50 \cdot 5 \pm 6 \cdot 6$ & $82 \pm 20$ & $28 \cdot 3 \pm 6 \cdot 4$ & $2 \cdot 67 \pm 0.21$ \\
\hline (2) & $\begin{array}{l}\text { Intact female }+ \\
\text { AS }(50 \mu \mathrm{l})\end{array}$ & $29 \cdot 0 \pm 1 \cdot 2$ & ND & ND & $29 \cdot 5 \pm 1 \cdot 7$ & $4.85 \pm 0.47$ \\
\hline (3) & $\begin{array}{l}\text { Intact female }+ \\
\text { AS }(10 \mu 1)\end{array}$ & $53 \cdot 9 \pm 2 \cdot 9$ & $52 \cdot 7 \pm 8 \cdot 7$ & $64 \pm 15$ & $32 \cdot 0 \pm 5 \cdot 5$ & $2 \cdot 9 \pm 0.06$ \\
\hline (4) & $\begin{array}{l}\text { Ovx normal female }+ \\
\text { vehicle }\end{array}$ & $28 \cdot 18 \pm 2 \cdot 9$ & $263 \pm 17$ & $756 \pm 48$ & $18 \cdot 4 \pm 2 \cdot 7$ & $14 \cdot 5 \pm 1 \cdot 5$ \\
\hline (5) & $\begin{array}{l}\text { Ovx normal female }+ \\
\text { AS }(50 \mu \mathrm{l})\end{array}$ & $14 \cdot 28 \pm 1 \cdot 6$ & $48 \cdot 7 \pm 8 \cdot 0$ & $154 \pm 25$ & $39 \cdot 2 \pm 5 \cdot 4$ & $23 \cdot 2 \pm 1 \cdot 5$ \\
\hline (6) & $\begin{array}{l}\text { Ovx normal female }+ \\
\text { AS }(10 \mu 1)\end{array}$ & $18 \cdot 18 \pm 1 \cdot 6$ & $32 \cdot 8 \pm 9 \cdot 2$ & $216 \pm 25 \cdot 7$ & $37 \cdot 5 \pm 4 \cdot 5$ & $21 \cdot 23 \pm 2 \cdot 2$ \\
\hline (7) & $\begin{array}{l}\text { Ovx normal female }+ \\
\text { AS }(5 \mu \mathrm{l})\end{array}$ & $16 \cdot 7 \pm 1 \cdot 2$ & $60 \cdot 4 \pm 10 \cdot 7$ & $307 \cdot 4 \pm 41 \cdot 9$ & $42 \cdot 8 \pm 6 \cdot 9$ & $14.4 \pm 0.94$ \\
\hline & $\begin{array}{l}\text { Ovx normal female }+ \\
\text { AS }(2 \mu \mathrm{l})\end{array}$ & $26 \cdot 1 \pm 2 \cdot 7$ & $121 \pm 24$ & $576 \pm 71$ & $35.8 \pm 2.9$ & $15 \cdot 79 \pm 1 \cdot 8$ \\
\hline
\end{tabular}

Values are mean \pm s.e.m. ( 5 mice/group).

See text for significance of differences between groups.

$\mathrm{ND}=$ not detectable $(<25 \mathrm{ng} \mathrm{LH} / \mathrm{ml}$ serum; $<50 \mathrm{ng} \mathrm{FSH} / \mathrm{ml}$ serum $)$. 
Treatment of intact normal female mice with $50 \mu \mathrm{GnRH}$ antiserum decreased GnRH receptors by $45 \%$ (Table 1 , Group 1 vs Group 2, $P<0.001$ ) and rendered serum LH and FSH undetectable. However, $10 \mu \mathrm{GnRH}$ antiserum in intact females did not change any of the characteristics measured (Group 1 vs Group 3). As previously observed (Naik et al., 1984b), ovariectomy resulted in a 40\% decrease in GnRH receptors (Group 4 vs Group 1) $(P<0.001)$. Treatment of ovariectomized normal female mice with $50 \mu \mathrm{l} \mathrm{GnRH}$ antiserum further decreased GnRH receptors by $50 \%$ (Group 4 ss Group 5, $P<0.001$ ), and the post-ovariectomy rise in serum gonadotrophins was prevented $(P<0.001)$.

Treatment of ovariectomized female mice with decreasing amounts of $\mathrm{GnRH}$ antiserum caused a dose-dependent increase of the receptor levels, from 14.28 $\pm 1.6(50 \mu \mathrm{l})$ to $26.1 \pm 2.7(2 \mu \mathrm{l})$ fmol/pituitary. The lowest dose $(2 \mu \mathrm{l})$ did not influence the receptors (Group 4 ss Group 8). The fall in receptor concentration with increasing amount of GnRH antiserum was associated with decreasing serum LH concentration, from $121 \pm 24(2 \mu \mathrm{l})$ to $48.7 \pm 8.0(50 \mu \mathrm{l}) \mathrm{ng} / \mathrm{ml}$. Similarly, a dose-dependent decrease in serum FSH occurred, reaching a minimum value of $154 \pm 25 \mathrm{ng} / \mathrm{ml}$ with the $50 \mu$ d dose of antiserum. As shown in Table 1, pituitary FSH values in ovariectomized females (Group 4) were 5-fold higher than in untreated intact controls (Group 1), and 50 and $10 \mu 1$ GnRH antiserum significantly augmented the pituitary FSH rise (Groups 5 and 6 vs Group 4, $P<$ 0.05 ). Treatment of intact females with $50 \mu \mathrm{l}$ antiserum increased pituitary FSH 2-fold (Group $2 v s$ Group 1, $P<0.001$ ), while $10 \mu$ antiserum were ineffective in this respect (Group 3 vs Group 1).

In contrast to the pituitary FSH rise in ovariectomized females, pituitary LH remained unchanged (Group 1 vs Group 4 NS). However, treatment with antiserum (all doses) increased pituitary LH content in ovariectomized females whereas similar treatment of intact females had no effect on pituitary LH content (Groups 2 and 3 vs Group 1).

In 5 separate experiments in which mice were injected s.c. with $50 \mu \mathrm{l}$ antiserum/day for 5-7 days to intact and ovariectomized normal females, a $30-50 \%$ fall in pituitary GnRH receptors, accompanied by suppression of serum gonadotrophins, was consistently observed. The same dose of antiserum also decreased GnRH receptors (fmol/pituitary) by 50 and $65 \%$ in intact and castrated normal male mice (intact control 40.0 \pm 1.9 ; intact + antiserum $20.4 \pm 1 \cdot 5$; castrate $32.9 \pm 2.3$; castrate + antiserum $11.5 \pm 1 \cdot 3$ ). This treatment suppressed serum gonadotrophin levels in intact male mice to undetectable values and prevented the post-castration rise of serum gonadotrophin values (not shown). GnRH receptors were also decreased by $60 \%$ when determined by Scatchard analysis of GnRH-A binding to pooled pituitary homogenate from male mice treated with $50 \mu \mathrm{l}$ antiserum once daily for 5 days $(25.27 \mathrm{fmol} /$ pituitary) compared with untreated intact controls $(62.05 \mathrm{fmol} /$ pituitary $)$, but there was no change in receptor affinity $\left(K_{\mathrm{a}}=1.9 \times 10^{9}\right.$ and $2.7 \times 10^{9}$ $\mathrm{M}^{-1}$ respectively). However, similar antiserum treatment $(50 \mu \mathrm{l} /$ day for 7 days $)$ did not change GnRH receptors ( $\mathrm{fmol} /$ pituitary) in $h p g$ male mice (15.0 \pm 2.5 in $h p g$ control, $15.5 \pm 2.0$ in $h p g+$ antiserum), and there was no effect on serum LH and FSH values, which remained undetectable in treated and control groups.

\section{The effect of multiple GnRH injections in normal and previously ovariectomized normal female mice}

Five injections of GnRH daily ( $60 \mathrm{ng} /$ injection) were given to groups of intact normal mice and mice that had been ovariectomized 7 days earlier. The dose chosen had previously been shown to stimulate gonadotroph function in hpg mice (Young et al., 1983), and the frequency of injections was on the basis that 3-4 injections of $\mathrm{GnRH} /$ day increase GnRH receptors in rats (Marshall et al., 1983). Groups of intact normal and 7-day ovariectomized females were injected with vehicle (PBS $+0.1 \% \mathrm{BSA})$ and served as controls. The injections were given every $4 \mathrm{~h}$ during the day, the last injection being at $23: 00 \mathrm{~h}$, and the next one at $07: 00 \mathrm{~h}$. The treatment was continued for 4 days, and the animals were killed $8 \mathrm{~h}$ after the last injection.

Multiple injections of $\mathrm{GnRH}$ to intact normal female mice increased $\mathrm{GnRH}$ receptors by $35 \%$ $(55.3 \pm 2.4$ and $74.1 \pm 2.8 \mathrm{fmol} /$ pituitary: $P=0.005)($ Text-fig. 1$)$. This was not accompanied by 
any change in serum FSH concentration or in pituitary LH and FSH content. However, serum LH values were reduced from $67.7 \pm 2$ to $19.5 \pm 1 \mathrm{ng} / \mathrm{ml}$. Identical $\mathrm{GnRH}$ treatment of 7-day ovariectomized female mice was without effect on pituitary GnRH receptors, serum FSH or pituitary FSH. As in intact GnRH-treated female mice, serum LH was markedly suppressed from high post-ovariectomy values $(231 \pm 42 \mathrm{ng} / \mathrm{ml})$ to values $(24 \pm 2 \cdot 2 \mathrm{ng} / \mathrm{ml})$ that were significantly $(P$ $<0.005)$ below those of untreated intact female mice $(67.7 \pm 2 \mathrm{ng} / \mathrm{ml})$. Pituitary LH content was also reduced $(P<0.001)$ in ovariectomized females treated with $\mathrm{GnRH}$.

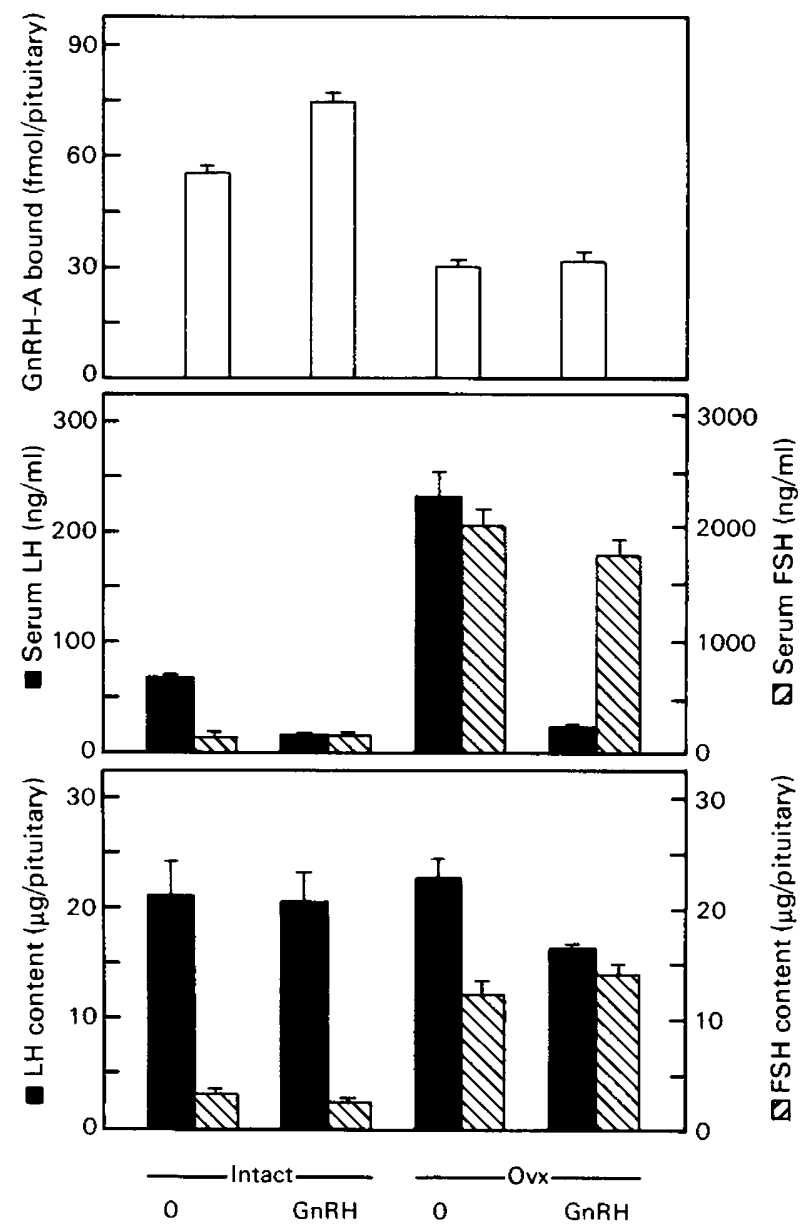

Text-fig. 1. Effect of multiple injections of GnRH $(5 \times 60 \mathrm{ng}$ for 4 days) on (a) GnRH receptors, (b) serum LH and FSH concentrations and (c) pituitary LH and FSH content in normal mice and those ovariectomized 7 days earlier. Lower limit of detection for serum $\mathrm{LH}=$ $19 \mathrm{ng} / \mathrm{ml}$. Values represent the mean \pm s.e.m. of 6 animals/group.

\section{The effect of GnRH treatment immediately after ovariectomy}

GnRH (60 ng) or vehicle was injected at 8-h intervals for $24 \mathrm{~h}$ or 4 days to ovariectomized mice, starting at the time of ovariectomy. Control animals were injected for the same time with vehicle alone. The animals were killed $8 \mathrm{~h}$ after the last injection. When measured $32 \mathrm{~h}$ after ovariectomy $(50.2 \pm 4$ compared with $66.5 \pm 3.9 \mathrm{fmol} /$ pituitary in intact females; $P=0.05 ; n=$ 5), the fall in GnRH receptors was not as marked as at 5 or 7 days after ovariectomy (Naik et al., 
1984b). Three injections of GnRH accentuated rather than prevented this early receptor fall (ovariectomy $+\mathrm{GnRH}=37.0 \pm 4.3 \mathrm{fmol} /$ pituitary, $P=<0.05$ s ovariectomy alone at $32 \mathrm{~h}$ ). If the GnRH treatment was continued for 4 days from the time of ovariectomy it neither accentuated nor prevented the receptor fall (intact female control $=63.3 \pm 3.4 \mathrm{fmol} /$ pituitary, $n=5$; ovariectomy alone $(4$ days $)=46.2 \pm 3.0 ;$ ovariectomy $+\mathrm{GnRH}=49.5 \pm 4.0 ; P=<0.01 \mathrm{vs}$ intact control for ovariectomy with or without $\mathrm{GnRH}$ ).

Effect of oestradiol and progesterone in intact and ovariectomized normal female mice treated with GnRH antiserum

The dose of antiserum $(50 \mu \mathrm{l})$ was chosen on the basis of the dose-response study data. Groups of normal female mice were ovariectomized and injected with (i) $50 \mu \mathrm{l} \mathrm{GnRH}$ antiserum; (ii) $300 \mathrm{ng}$ oestradiol/day plus $375 \mu \mathrm{g}$ progesterone/day; (iii) the combination of (i) and (ii); or (iv) vehicle alone (sesame oil), once daily for 7 days starting at the time of ovariectomy. Groups of intact normal female mice were similarly treated. All the injections were in $0.1 \mathrm{ml}$. Animals were killed $24 \mathrm{~h}$ after the last injection of steroids and antiserum.

GnRH antiserum $(50 \mu \mathrm{l} /$ day) treatment of intact and ovariectomized female mice reduced GnRH receptors by 40\% (Group $1 v s$ Group 2, $P<0.001$; Group 5 vs Group 6, $P<0.001$; Table 2). Administration of oestradiol and progesterone to ovariectomized mice treated with GnRH antiserum (Group 6) increased GnRH receptors 3-fold compared to values for Group 7 (ovariectomy + antiserum) $(P<0.001)$. The receptor values in Group 7 mice were identical to those of ovariectomized animals receiving steroids without antiserum (Group 8; NS) but did not reach the values for intact females (Group 1). However, steroid treatment of intact female mice receiving antiserum (Group 3) did not prevent the inhibitory effect of antiserum on receptor numbers (Group 2) (Group 3 vs Group 1, $P<0.01$ ). Although intact female mice treated with steroids but not antiserum (Group 4) had a 30\% reduction in GnRH receptors compared to Group 1 , these values were significantly higher $(P<0.05)$ than those of ovariectomized mice treated with steroids only (Group 8).

Table 2. Effects of oestradiol $\left(E_{2}\right)+$ progesterone $(P)$ in intact and ovariectomized (Ovx) normal female mice treated with GnRH antiserum (AS)

\begin{tabular}{|c|c|c|c|c|c|}
\hline Groups & $\begin{array}{l}\text { GnRH receptor } \\
\text { (fmol/pituitary) }\end{array}$ & $\underset{(\mathrm{ng} / \mathrm{ml})}{\text { Serum LH }}$ & $\begin{array}{c}\text { Serum FSH } \\
(\mathrm{ng} / \mathrm{ml})\end{array}$ & $\begin{array}{l}\text { Pituitary LH } \\
\text { (ug/pituitary) }\end{array}$ & $\begin{array}{c}\text { Pituitary FSH } \\
(\mu \mathrm{g} / \text { pituitary })\end{array}$ \\
\hline $\begin{array}{l}\text { (1) Intact female } \\
+ \text { vehicle }\end{array}$ & $71 \cdot 56 \pm 5 \cdot 2$ & $52 \cdot 6 \pm 8 \cdot 7$ & $120 \pm 43$ & $45 \cdot 5 \pm 5 \cdot 1$ & $2 \cdot 42 \pm 0.39$ \\
\hline $\begin{array}{l}\text { (2) Intact female } \\
+\mathrm{AS}\end{array}$ & $41.5 \pm 3 \cdot 1$ & $26.93 \pm 3.8$ & $57 \pm 5 \cdot 0$ & $46 \cdot 9 \pm 2 \cdot 7$ & $4.85 \pm 0.47$ \\
\hline $\begin{array}{l}\text { (3) Intact female } \\
+\mathrm{AS}+\mathrm{E}_{2}+\mathrm{P}\end{array}$ & $45.57 \pm 2 \cdot 2$ & ND & $<50$ & $34 \cdot 2 \pm 3 \cdot 6$ & $3 \cdot 37 \pm 0 \cdot 18$ \\
\hline $\begin{array}{l}\text { (4) Intact female } \\
+E_{2}+P\end{array}$ & $52 \cdot 4 \pm 4 \cdot 2$ & $24 \cdot 6 \pm 5 \cdot 1$ & $<50$ & $39 \cdot 4 \pm 4 \cdot 2$ & $3 \cdot 1 \pm 0 \cdot 16$ \\
\hline (5) Ovx + vehicle & $25 \cdot 7 \pm 2 \cdot 4$ & $274 \pm 34$ & $652 \pm 35$ & $55 \cdot 6 \pm 3 \cdot 1$ & $8 \cdot 0 \pm 0.37$ \\
\hline (6) Ovx + AS & $15 \cdot 0 \pm 2 \cdot 5$ & $48 \cdot 7 \pm 8 \cdot 1$ & $254 \pm 22$ & $57 \cdot 8 \pm 2 \cdot 2$ & $9.2 \pm 0.44$ \\
\hline $\begin{array}{l}\text { (7) } \mathrm{Ovx}+\mathrm{AS}+ \\
\mathrm{E}_{2}+\mathrm{P}\end{array}$ & $45 \cdot 0 \pm 4 \cdot 7$ & ND & $204 \pm 17$ & $41.9 \pm 0.42$ & $7 \cdot 85 \pm 0 \cdot 34$ \\
\hline (8) $\mathrm{Ovx}+\mathrm{E}_{2}+\mathrm{P}$ & $40 \cdot 0 \pm 0 \cdot 24$ & $26 \cdot 4 \pm 7 \cdot 3$ & $240 \pm 23$ & $40 \cdot 9 \pm 4 \cdot 2$ & $8 \cdot 24 \pm 0 \cdot 31$ \\
\hline
\end{tabular}

Values are the mean \pm s.e.m. for 5-6 animals/group. See text for significance of difference between groups. $\mathrm{ND}=$ undetectable $(<20 \mathrm{ng} \mathrm{LH} / \mathrm{ml}$ serum $)$. 
As shown in Table 2, GnRH antiserum or steroid treatment of intact female mice significantly $(P<0.001)$ reduced serum $\mathrm{LH}$ and FSH values to just detectable levels, whereas in the previous study (Table 1) both hormones were rendered undetectable by the same dose of antiserum. However, steroid treatment in combination with GnRH antiserum rendered serum LH undetectable in intact and ovariectomized animals. In intact females serum FSH was halved by antiserum treatment and rendered undetectable by steroid treatment either alone or when combined with antiserum. However, steroid treatment of ovariectomized females did not produce further suppression of serum FSH when combined with GnRH antiserum than did the antiserum alone (Groups 6, 7 and 8 vs Group 5, $P=<0.001$; Groups 7 and 8 vs Group 6, NS).

Treatment of intact normal female mice with antiserum or steroids or their combination had no significant effect on pituitary LH content (NS, for all treated groups), although pituitary FSH was increased 2-fold $(P<0.01)$ by antiserum treatment alone. Pituitary LH in ovariectomized females was not significantly increased compared to intact female values and remained unchanged by antiserum treatment alone, while treatment with steroids with or without antiserum reduced pituitary LH by $25 \%$ (Groups 9 and 8 vs Group 5, $P<0.05$ ). However, pituitary FSH in ovariectomized females was increased 3-4-fold $(P<0.001)$ compared to intact controls, but none of the treatments had any effect compared to the values for the respective vehicle-treated controls.

\section{Discussion}

The most striking finding of these experiments was not only the failure of GnRH immunoneutralizatoin to prevent the post-ovariectomy GnRH receptor fall but the fact that this fall was accentuated. The GnRH antiserum treatment was clearly effective at abolishing pituitary stimulation by endogenous GnRH since it prevented the post-ovariectomy rise in serum gonadotrophins. Therefore, the proposal (Naik et al., 1984a) that the post-ovariectomy fall in GnRH receptors resulted from receptor occupancy or down-regulation consequent upon increased endogenous GnRH secretion seems most unlikely. Further evidence against increased receptor occupancy/down-regulation was the observation that additional repetitive exogenous GnRH treatment of ovariectomized mice did not further reduce $\mathrm{GnRH}$ receptors.

It might be argued that the $\mathrm{GnRH}$ antiserum itself cross-reacted with the $\mathrm{GnRH}$ receptor in vivo leading to reduced ligand-receptor interaction in the in-vitro radioreceptor assay and that this was the explanation of the further reduction in $\mathrm{GnRH}$ receptors in the ovariectomized $\mathrm{GnRH}$ antiserum treated mice. However, this could not be the case because the same treatment of GnRHdeficient hpg mice did not reduce the already low concentration of $\mathrm{GnRH}$ receptors. Furthermore, in-vitro experiments have clearly demonstrated that this antiserum does not interact with GnRH receptors (Clayton et al., 1982).

The observation that the GnRH antiserum further reduced $\mathrm{GnRH}$ receptors in ovariectomized mice probably indicates that endogenous $\mathrm{GnRH}$, acting directly on the gonadotroph, is required even to maintain the reduced number of GnRH receptors. This conclusion also applies to male mice, based on a similar reduction in receptors after castration and $\mathrm{GnRH}$ antiserum treatment. $\mathrm{GnRH}$ receptor levels in ovariectomized and antiserum-treated mice were very similar to those of untreated hpg female mice (Naik et al., 1985), indicating that the antiserum treatment had induced GnRH deficiency in the normal ovariectomized females. Further evidence for a role of GnRH in receptor maintenance in mice is provided from the studies of intact male and female animals in which GnRH antiserum reduced the receptor complement, as is the case with intact rats so treated (Frager et al., 1981; Clayton et al., 1982). In addition, GnRH treatment of hpg male (Young et al., 1983; Detta, Naik, Charlton, Young \& Clayton, 1984) and female (Naik et al., 1985) mice indicates that homologous ligand up-regulation of its own receptors clearly occurs in mice, as in rats. The fact that this up-regulation occurs to the same extent in gonadectomized hpg animals indicates that it is 
the result of GnRH acting directly on the gonadotroph, rather than being secondary to GnRH stimulation of gonadal steroids which can also up-regulate GnRH receptors at least in mice (Naik et al., 1985).

The hypothesis of homologous ligand GnRH-receptor autoregulation was based entirely on studies in rats (Clayton \& Catt, 1981b; Marshall et al., 1983, for review) and was that GnRH was the primary hormonal regulator of pituitary GnRH receptor content. The corollary to this is that GnRH receptor levels reflect the prior exposure of the pituitary to endogenous GnRH. On this basis the post-gonadectomy fall in GnRH receptors in mice should represent a relative deficiency of endogenous GnRH secretion, an unlikely explanation in view of the high serum gonadotrophin concentrations observed. If this were the case then exogenous GnRH should prevent or reverse the receptor fall after ovariectomy. However, treatment of 7-day ovariectomized or immediately ovariectomized mice with $\mathrm{GnRH}$, in a dose previously shown to elevate GnRH receptors in hpg mice (Young et al., 1983), was completely unable to restore or prevent the receptor fall. It is unlikely that the GnRH 'replacement' regimens were inappropriate since with the 5 times per day regimen for 4 days pituitary LH desensitization occurred as high post-ovariectomy serum LH levels were reduced to intact control values. Moreover the same treatment schedule significantly increased $\mathrm{GnRH}$ receptors in intact female mice. Failure of exogenous GnRH to influence the receptor fall in mice after ovariectomy clearly indicates that the fall is unrelated to reduced pituitary exposure to endogenous GnRH. Therefore, the view that pituitary GnRH-receptor content reflects solely the degree of exposure to endogenous GnRH clearly does not apply to the post-gonadectomy state in mice, in which the post-ovariectomy receptor fall is independent of changes in endogenous hypothalamic GnRH secretion.

While this study indicates that exogenous GnRH can up-regulate GnRH receptors in intact female mice, this was dependent upon the gonads and therefore all the changes in GnRH receptors in vivo are not necessarily a consequence of direct GnRH action on the gonadotroph. Gonadal steroids, increased secondarily to GnRH-stimulated gonadotrophin release, acting directly on the pituitary (Loumaye \& Forni, 1982) may also be involved.

We have previously reported (Naik et al., 1984b) that oestrogen, and oestrogen combined with progesterone, can largely, although not completely, reverse the $\mathrm{GnRH}$ receptor fall after ovariectomy of mice with intact hypothalamic GnRH secretion. Although unlikely from the evidence discussed above, it was possible that gonadal steroid reversal of the post-ovariectomy receptor fall resulted from a subtle change in endogenous GnRH secretion which in turn stimulated GnRH receptor increase. This possibility is rendered even more unlikely by the finding that oestradiol and progesterone can elevate GnRH receptors in ovariectomized mice in which endogenous $\mathrm{GnRH}$ has been immunoneutralized. This provides direct evidence that oestradiol and progesterone act at the level of the gonadotroph to increase GnRH receptors, and that the postovariectomy fall in receptors results from removal of the receptor-maintaining influence of gonadal steroids. GnRH receptor regulation in female mice is therefore multifactorial, gonadal steroids being the primary regulator and homologous ligand up-regulation by $\mathrm{GnRH}$ having a secondary role. Thus, the receptor fall in intact female mice after GnRH immunoneutralization is a consequence not only of removal of the up-regulatory action of the ligand but also of the secondary hypogonadism that ensues.

In several experiments we have observed that treatment of intact female mice with oestradiol and progesterone reduces GnRH receptors to below untreated control values which are similar to those of ovariectomized females treated with oestradiol and progesterone. This, and the failure of steroid treatment to restore GnRH receptors to intact female values indicates that the steroid treatment suppresses endogenous GnRH secretion with the result that GnRH receptors fall in the intact animals and fail to reach intact values in the ovariectomized oestradiol + progesteronetreated group.

In rats there is often a positive correlation between pituitary GnRH receptors and serum gonadotrophin concentrations, particularly LH (reviewed by Clayton \& Catt, 1981a). This 
correlation is not as apparent in mice (Naik et al., 1984a, b). The present study with mice also highlights the discrepancy between changes in GnRH receptor and serum LH levels. LH densensitization occurred in intact and ovariectomized mice treated with GnRH when GnRH receptors either increased or remained unchanged, respectively. However, serum FSH values did not change, indicating the relative resistance of FSH to desensitization, at least in these experiments. In addition, oestrogen and progesterone treatment of ovariectomized mice suppressed both high serum LH and FSH levels while increasing GnRH receptors. Therefore, the regulation of gonadotrophin secretion both by $\mathrm{GnRH}$ and ovarian steroids in mice is largely independent of GnRH receptor changes and presumably occurs at post-receptor sites. This conclusion was also reached from earlier studies of rats in vivo (Clayton, 1982). Pituitary desensitization by GnRH in vitro also occurs at post-receptor sites (Smith, Perrin \& Vale, 1983; L. S. Young \& R. N. Clayton, unpublished data), being largely independent of GnRH receptor down-regulation. Moreover, the $\mathrm{LH}$ desensitization by $\mathrm{GnRH}$ could not be accounted for by reduced pituitary LH synthesis in vitro (Smith et al., 1983) or in vivo in the present experiments since LH content was unchanged in intact female mice and only marginally reduced in the ovariectomized group.

In the present experiments there were variable effects of $\mathrm{GnRH}$ antiserum treatment on pituitary gonadotrophin content, while both serum gonadotrophins were consistently suppressed. In ovariectomized animals treated for 5 days with antiserum pituitary $\mathrm{LH}$ and FSH were increased, although this was not observed with 7 days of antiserum treatment. The reason for this is not clear, although between 4 and 7 days pituitary LH content is beginning to rise after an initial fall after ovariectomy (Naik et al., 1984b). Nevertheless, it is apparent that gonadotrophin biosynthesis, at least in the short term, proceeds despite marked reduction in GnRH receptors and GnRH stimulation of the pituitary. The increased pituitary LH content after ovariectomy was prevented by gonadal steroid treatment both in the presence and absence of concurrent GnRH immunoneutralization. Therefore, at least a component of the negative feedback action of oestradiol and progesterone on gonadotrophin synthesis is exerted at the pituitary level.

In summary, the GnRH receptor fall after ovariectomy of mice is not a consequence of altered endogenous GnRH secretion, but results primarily from removal of the receptor-maintaining action of oestradiol and progesterone. Nevertheless, a minor component of homologous ligand receptor regulation is evident after ovariectomy of normal female mice, although in these animals the gonads are essential for receptor up-regulation by exogenous GnRH. A marked discrepancy between hormonal regulation of $\mathrm{GnRH}$ receptors and gonadotrophin secretion indicates the complexity of the inter-relationship between these events.

We thank Dr H. M. Fraser, MRC Unit of Reproductive Biology, Edinburgh, for supplies of the GnRH antiserum. The work was supported by grants from the MRC (R.N.C. and H.M.C.), the Central Birmingham Health District Social Trustees (I.S.Y.) and the Government of Pakistan (S.I.N.).

\section{References}

Arimura, A., Debeljuk, L. \& Schally, A.V. (1974) Blockade of the preovulatory surge of LH and FSH and of ovulation by anti LH-RH serum in rats. Endocrinology 95, 323-325.

Clayton, R.N. (1982) Gonadotrophin-releasing hormone modulation of its own pituitary receptors: evidence for biphasic regulation. Endocrinology 111, 152-161.

Clayton, R.N. \& Catt, K.J. (1981a) Regulation of pituitary gonadotrophin releasing hormone receptors by gonadal hormones. Endocrinology 108, 887-895.
Clayton, R.N. \& Catt, K.J. (1981b) Gonadotrophinreleasing hormone receptors : characterisation, physiological regulation, and relationship to reproductive function. Endocr. Rev. 2, 186-209.

Clayton, R.N., Popkin, R.M. \& Fraser, H.M. (1982) Hypothalamic regulation of pituitary gonadotrophin releasing hormone receptors. Effects of gonadotrophin releasing hormone immunoneutralization. Endocrinology 110, 1116-1123.

Conn, P.M., Rogers, D.C. \& Seay, S.G. (1984) Biphasic 
regulation of the $\mathrm{GnRH}$ receptor by receptor microaggregation and intracellular $\mathrm{Ca}^{2+}$ levels. Molec. Pharmac. 25, 51-55.

Conne, B.S., Scaglioni, S., Lang, U., Sizonenko, P.C. \& Aubert, M.L. (1982) Pituitary receptor sites for GnRH; effects of castration and substitutive therapy with sex steroids in the male rat. Endocrinology 110, 70-79.

Detta, A., Naik, S.I., Chariton, H.M., Young, L.S. \& Clayton, R.N. (1984) Homologous ligand induction of pituitary gonadotrophin releasing hormone receptors in vivo is protein synthesis dependent. Molec. cell. Endocr. 37, 139-144.

Frager, M.G., Pieper, D.R., Tonetta, S., Duncan, J.A. \& Marshall, J.C. (1981) Pituitary gonadotrophin releasing hormone ( $\mathrm{GnRH}$ ) receptors : effects of castration, steroid replacement and the role of $\mathrm{GnRH}$ in modulating receptors in the rat. J. clin. Invest. 67, 615-623.

Fraser, H.M. \& McNeilly, A.S. (1982) Effects of immunoneutralization of luteinizing hormone-releasing hormone surges in the ewe. Biol. Reprod. 27, 548555 .

Kawakami, M. \& Higuchi, T. (1979) Effects of active and passive immunization with LH-RH on the gonadotrophin secretion in the female rat. Acta endocr., Copenh. 91, 616-628.

Loumaye, E. \& Catt, K.J. (1982) Homologous regulation of gonadotrophin-releasing hormone receptors in cultured pituitary cells. Science, N.Y. 215, 983-985.

Loumaye, E. \& Forni, L. (1982) Regulatory actions of $17 \beta$-estradiol and progesterone upon pituitary $\mathrm{GnRH}$ receptors in vitro. Endocrinology 110, Suppl., p. 286, Abstr. 825.
Marshall, J.C., Barkan, A., Bourne, G.A., Duncan, J.A., Garcia-Rodriguez, A., Pieper, D.A. \& Regiani, S. (1983) Physiology of pituitary gonadotrophin releasing hormone receptors. In Recent Advances in Male Reproduction: Molecular Basis and Clinical Implications, pp. 205-213. Eds R. D. Agata, M. Lipsett, P. Polosa \& H. J. van der Molen. Raven Press, New York.

Naik, S.I., Young, L.S., Charlton, H.M. \& Clayton, R.N. (1984a) Pituitary gonadotrophin-releasing hormone receptor regulation in mice. I. Males. Endocrinology 115, 106-113.

Naik, S.I., Young, L.S., Charlton, H.M. \& Clayton, R.N. (1984b) Pituitary gonadotrophin-releasing hormone receptor regulation in mice. II. Females. Endocrino$\log y 115,114-120$.

Naik, S.I., Young, L.S., Charlton, H.M. \& Clayton, R.N. (1985) Evidence for a pituitary site of gonadal steroid stimulation of $\mathrm{GnRH}$ receptors in female mice. $J$. Reprod. Fert. 74, 615-624

Smith, M.A., Perrin, M.H. \& Vale, W.W. (1983) Densensitization of cultured pituitary cells to gonadotrophin releasing hormone: evidence for a postreceptor mechanism. Molec. cell. Endocr. 30, 85-96.

Young, L.S., Speight, A., Charlton, H.M. \& Clayton, R.N. (1983) Pituitary gonadotrophin releasing hormone receptor regulation in the hypogonadotrophic hypogonadal (hpg) mouse. Endocrinology 113, 55-61.

Young, L.S., Naik, S.I. \& Clayton, R.N. (1984) Adenosine 3',5'-monophosphate derivatives induce GnRH receptors in cultured pituitary cells. Endocrinology 114, 2114-2122.

Received 18 October 1984 